\title{
Data report: Pliocene-Pleistocene planktonic foraminifer bioevents at IODP Site U1313'
}

\author{
F.J. Sierro, ${ }^{2}$ I. Hernandez-Almeida, ${ }^{2}$ M. Alonso-Garcia, ${ }^{2}$ and J.A. Flores ${ }^{2}$
}

\section{Chapter contents}

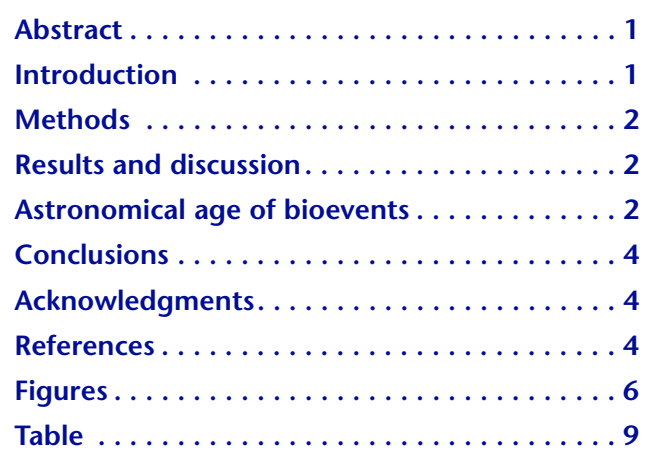

'1Sierro, F.J., Hernandez-Almeida, I., Alonso-Garcia, M., and Flores, J.A., 2009. Data report: PliocenePleistocene planktonic foraminifer bioevents at IODP Site U1313. In Channell, J.E.T., Kanamatsu, T., Sato, T., Stein, R., Alvarez Zarikian, C.A., Malone, M.J., and the Expedition 303/306 Scientists, Proc. IODP, 303/306: College Station, TX (Integrated Ocean Drilling Program Management International, Inc.).

doi:10.2204/iodp.proc.303306.205.2009

2Department of Geology, Group of Oceanic Geosciences, Faculty of Sciences, University of Salamanca, 37008 Salamanca, Spain.

Correspondence author: sierro@usal.es

\section{Abstract}

We performed a quantitative study of some planktonic foraminifer species from Integrated Ocean Drilling Program Site U1313 to define main biostratigraphic events. Some of these events were characterized by large changes in species abundance rather than their first or last occurrences. Changes in relative abundances of planktonic foraminifers were compared to the color reflectance and magnetostratigraphic records measured at this site. We obtained astronomical ages for all these events through calibration to the isotope timescale. Comparison of these ages with the astronomical dates derived from the Mediterranean indicates that most of the events were synchronous in the mid-latitudes of the North Atlantic and the Mediterranean.

\section{Introduction}

Planktonic foraminifers have been very useful in elaborating biostratigraphic studies for the Pliocene and Pleistocene in the North Atlantic (Berggren, 1984; Berggren et al., 1985; Weaver, 1987; Weaver and Clement, 1986, 1987; Raymo et al., 1989). Most of these studies are based on the distribution of some species of Globorotaliids, such as Globorotalia puncticulata, Globorotalia margaritae, Globorotalia inflata, or Globorotalia truncatulinoides, as well as Neogloboquadrina pachyderma sinistral or Neogloboquadrina atlantica. Some of these species, however, show a preferential habitat in the temperate and subtropical regions, and consequently their distribution is not synchronous throughout the North Atlantic. This is the case with G. margaritae, which disappeared first from the northern latitudes of the North Atlantic (Weaver and Clement, 1986). Other species, such as G. truncatulinoides or G. puncticulata, are rarely distributed in the northernmost regions of the North Atlantic, and therefore their use is limited to the mid-latitudes.

Globorotaliids were also used to construct biostratigraphic scales in the Mediterranean (Cita, 1973; Iaccarino, 1985). Biostratigraphic events in this region were calibrated to the astronomical timescale through the tuning of rhythmic sedimentary cycles to astronomical solutions (Hilgen, 1991a, 1991b; Lourens et al., 1996a, 1996b, 1998), which gave very accurate ages with a precision lower than a precession cycle. 
In this study we performed a quantitative study of some planktonic foraminifer species from Integrated Ocean Drilling Program Site U1313 in order to define and locate the main biostratigraphic events for this site and to compare these ages with the astronomical dates derived from the Mediterranean cyclical sections.

\section{Methods}

Samples from Site U1313 were washed through a 150 $\mu \mathrm{m}$ sieve, and the residue was split as many times as necessary to obtain an aliquot of between 300 and 600 specimens. Using a stereomicroscope, we identified the planktonic foraminifer specimens following the taxonomic concepts of Kennett and Srinivasan (1983) in order to estimate the relative abundance of those species that are relevant to elaborate the biostratigraphic framework.

\section{Results and discussion}

Our study shows the evolution of relative abundances of some planktonic foraminifer species through time with special emphasis on the first or last occurrences of these species (Figs. F1, F2). The interval of study extends from the early Pliocene to the present. See Table T1 for quantitative data.

\section{Early Pliocene events}

The latest Miocene to early Pliocene interval is dominated by the presence of G. margaritae, which is relatively abundant from the base of this site (Fig. F1). We recognized the last occurrence (LO) of this species between 185.29 and 182.25 meters composite depth (mcd). It never reached percentages above $10 \%$ of the assemblage. Because of the low resolution of our study for this part of the record, we are not able to accurately locate this event.

We also analyzed the early Pliocene abundance of $G$. puncticulata. The first occurrence (FO) of this species, which is a very useful event in the North Atlantic, was located between 213 and $207 \mathrm{mcd}$, and the LO was located between 114.6 and 115.02 mcd (Fig. F1). This species shows high percentages during the Pliocene, reaching $>30 \%$ of the total assemblage immediately above its FO. An interval in which this species is completely absent was observed in the middle part of its time range (Fig. F1). This absence allowed us to define two bioevents: (1) the temporary disappearance of $G$. puncticulata located between 168.92 and $164.97 \mathrm{mcd}$, and (2) its reappearance located at 153.8 mcd. Immediately after its reappearance, again $G$. puncticulata abundance reached very high percentages (Fig. F1).

\section{Late Pliocene-early Pleistocene events}

We analyzed the late Pliocene and Pleistocene quantitative changes of $G$. inflata, G. truncatulinoides, and $N$. pachyderma sinistral (Figs. F1, F2). These three species appear for the first time near the Pliocene/Pleistocene boundary.

After the LO of G. puncticulata, the Globorotaliids are almost absent from this site until the FO of $G$. inflata, located at $106.17 \mathrm{mcd}$, although only one specimen was found at this level. A short peak in abundance of this species appears at $101.73 \mathrm{mcd}$, followed by very low abundances. The sharp increase in abundance observed at 98.23 mcd was used to define the first abundant occurrence (FAO) of $G$. inflata (Fig. F1). From this level uphole G. inflata abundance varies greatly, reaching percentages $>40 \%$ of the assemblage during some intervals.

$N$. pachyderma sinistral is present at low percentages in the Pliocene and earliest Pleistocene and becomes very abundant between 82.43 and 83.92 mcd (Fig. F2). We used this change in abundance to define the FAO of this species. In addition, we studied the abundance of $N$. pachyderma dextral to calculate the percentage of $N$. pachyderma sinistral with respect to the total number of Neogloboquadrinids. The percentage of sinistral Neogloboquadrinids is very low during the Pliocene and earliest Pleistocene and then suddenly changes at $82.43 \mathrm{mcd}$ because of the large increase in abundance of $N$. pachyderma sinistral (Fig. F2).

We recognized a relatively long interval in which $N$. pachyderma sinistral is rare or absent that was used to define two new bioevents (Fig. F2). The temporary reduction in abundance of the species was observed between 66.4 and $64.85 \mathrm{mcd}$, whereas the increase in abundance was located between 56.35 and 57.85 mcd. In this interval with very low values of $N$. pachyderma sinistral, the dextral Neogloboquadrinids become dominant (Fig. F2).

Finally, we identified the FO of G. truncatulinoides between 94.81 and $96.31 \mathrm{mcd}$. This species does not reach percentages above $4 \%$ of the assemblage and is absent in many samples after its FO. Consequently, the accurate location of this bioevent should be analyzed with caution.

\section{Astronomical age of bioevents}

In Figure F3 we show the position of the bioevents defined in this study with respect to the magnetostratigraphic and lightness records measured at Site U1313 (Expedition 306 Scientists, 2005). The lightness record was correlated by Stein et al. (2006) to the global benthic oxygen isotope stack of Lisiecki 
and Raymo (2005), assuming that increasing lightness, which reflects higher carbonate values, correlates with interglacial isotope stages. In this way, we accurately correlated our events with the global isotope timescale.

Most of these events have been previously recorded in Mediterranean rhythmic sections and were calibrated with the geomagnetic polarity timescale and astronomical polarity timescale (Lourens et al., 1996a, 1996b, 1998). By comparing our records with those of the Mediterranean we were able to analyze the timing of these events at the site's latitude with the ages derived from the astronomically dated Mediterranean sections.

\section{FO of Globorotalia puncticulata}

This event was reported in the Mediterranean during insolation cycle (i-cycle) 435 (Lourens et al., 1996a) with an age of $4.52 \mathrm{Ma}$. It occurred two i-cycles below the top of the Nunivak Chron (i-cycle 433). At Site U1313 this event is located at a depth very close to the top of the Nunivak Chron ( 209 mcd) and is related by Lourens et al. (1996a) with isotope Stage N1-N2.

\section{LO of Globorotalia margaritae}

This bioevent is located in the Mediterranean within the upper part of the Gilbert Chron at i-cycle 367 with an age of 3.81 Ma (Lourens et al., 1996a) and was correlated with isotope Stages Gi16-Gi15. At Site U1313 we observed this event toward the middle part of Chron Gilbert. According to preliminary correlations between the lightness record from Site U1313 and the global oxygen isotope stack (Lisiecki and Raymo, 2005), the LO of G. margaritae at Site U1313 is located at a depth very close to the position of isotope Stage Gi16, indicating that this event can be isochronous between the Mediterranean and the North Atlantic at the latitude of this site.

\section{Disappearance of Globorotalia puncticulata}

This event has been observed in the Mediterranean during i-cycle 344 with an age of $3.57 \mathrm{Ma}$, only two i-cycles above the Gilbert/Gauss Chron boundary. This reversal is recorded at Site U1313 at 170 mcd, between 1 and $5 \mathrm{~m}$ below the location of this bioevent. According to preliminary correlations with the global oxygen isotope stack, this event is located at Site U1313 within the interval range of isotope Stages MG7-MG11 (Fig. F3). This bioevent was correlated with isotope Stage MG8 by Lourens et al. (1996a). Although the low resolution of our study for this part of the record does not allow an accurate location, our preliminary data suggest this event seems to be isochronous between the Mediterranean and Site U1313.

\section{Reappearance of Globorotalia puncticulata}

This event was astronomically dated in the Mediterranean at $3.31 \mathrm{Ma}$ and corresponding to i-cycle 317 , which is two i-cycles above the bottom of the Mammoth Chron (i-cycle 319). This corresponds to isotope Stage M2-M3 according to Lourens et al. (1996a). The event's location at Site U1313 was observed immediately above the bottom of the Mammoth Chron and coinciding with prominent glacial isotope Stage M2 (Fig. F3). This demonstrates that this event is synchronous between the Mediterranean and the North Atlantic at mid-latitudes.

\section{LO of Globorotalia puncticulata}

The astronomical age for this event in the Mediterranean is 2.41 Ma. It occurred during i-cycle 230, which is well above the Gauss/Matuyama Chron boundary. In this study we observed this event at the base of isotope Stage 95 (Fig. F3) according to the age model of Stein et al. (2006). Its age, based on the correlation to Lisiecki and Raymo (2005), is $2.418 \mathrm{Ma}$, which is exactly the same age as that reported for the Mediterranean. Furthermore, Lourens et al. (1996a) already related this event to isotope Stage 95.

\section{FAO of Globorotalia inflata}

As shown in Figure F3, this event is related to isotope Stage 78 based on the age model proposed by Stein et al. (2006). This event was dated at $2.09 \mathrm{Ma}$ by Lourens et al. (1996a) and related to i-cycle 203, which is three i-cycles above the top of the Reunion Chron. The FO of G. inflata in the Mediterranean is correlated with the FAO of the species at Site U1313 and was related with exactly the same isotope stage.

\section{FAO of Neogloboquadrina pachyderma sinistral}

This bioevent at Site U1313 lies within isotope Stages 63-64 (Fig. F3). In the Mediterranean it was reported during i-cycle 175 and was correlated with isotope Stage 64 with an age of $1.8 \mathrm{Ma}$ (Lourens et al., 1996a). It occurred during the Olduvai Chron, only one i-cycle below the top of the chron. This reversal at Site U1313 is at $82.82 \mathrm{mcd}, \sim 1 \mathrm{~m}$ above the FAO of $N$. pachyderma sinistral, which indicates that this event is located in the uppermost part of the Olduvai Chron. 


\section{Reduction of Neogloboquadrina pachyderma sinistral}

Previous studies identified an interval in the midPleistocene with very low abundances of $N$. pachyderma sinistral both in the Mediterranean (Lourens et al., 1996a, 1996b, 1998) and the North Atlantic (Raymo et al., 1989). This species, which usually peaks during glacial isotope stages, drastically reduced in abundance during glacial isotope Stages 42, 40 , and 38 in the Vrica/Crotone composite section in Italy and Deep Sea Drilling Project Site 607, which was drilled at the same location as Site U1313. This interval was also observed at Ocean Drilling Program Site 967 and Hole 969D (Lourens et al., 1998). We identified the last peak in abundance of this species during isotope Stage 46 (Fig. F3) but did not recognize the peak of isotope Stage 44, probably because of the low resolution of our study. However, highresolution studies at Site 607 (Raymo et al., 1989) show a peak in abundance of $N$. pachyderma sinistral in isotope Stage 44, whereas the species is almost absent during glacial Stages 42, 40, and 38. The reduction of N. pachyderma sinistral was dated in the Mediterranean with an age of $1.37 \mathrm{Ma}$ (Lourens et al., 1996a) and was correlated with i-cycle 131.

\section{Increase of Neogloboquadrina pachyderma sinistral}

The interval with low percentages of $N$. pachyderma sinistral ends with a sudden increase in abundance of this species during glacial isotope Stage 36 (Fig. F3). This was observed in the Mediterranean and the North Atlantic (Lourens et al., 1996a, 1996b, 1998; Raymo et al., 1989). We recognized this event at Site U1313 near the bottom of the Cobb Mountain Subchron during isotope Stage 36, with an estimated age of 1.21 Ma based on the correlation to the Lisiecki and Raymo (2005) isotope stack. It was astronomically dated in the Mediterranean with an age of 1.22 Ma and correlated with i-cycle 117.

\section{FO of Globorotalia truncatulinoides}

We observed this event within isotope Stage 77, 2-3 $\mathrm{m}$ below the bottom of the Olduvai Chron (Fig. F3). The age of this event, according to the age model of Stein et al. (2006), is $2.03 \mathrm{Ma}$. This event was not recognized in the Mediterranean.

\section{Conclusions}

Based on the quantitative analysis of some species of Globorotalia and Neogloboquadrina, we identified a series of bioevents at Site U1313 during the Pliocene and Pleistocene. These events were related with the color reflectance and magnetostratigraphic records obtained at the same site and correlated with the Lisiecki and Raymo (2005) global benthic oxygen isotope stack. A close comparison with biostratigraphic data obtained in astronomically dated sections from the Mediterranean demonstrates that most of these events were synchronous in the midlatitudes of the North Atlantic and the Mediterranean and are very useful for chronostratigraphic correlations. Our study also shows that a high-resolution quantitative study is necessary to characterize and precisely locate these events.

\section{Acknowledgments}

This work was funded by Ministerio de Educación y Ciencia Project GRACCIE (CONSOLIDER-INGENIO CSD 2007-00067), CGL 2005-00642/BTE, CGL200805560 and REN 2003-08642-CO2/CLI, as well as Project SA008C05 and GR34 funded by Junta de Castilla y León. We are very grateful to the Integrated Ocean Drilling Program (IODP) for providing the samples for this study.

\section{References}

Berggren, W.A., 1984. Neogene plankton foraminiferal biostratigraphy and biogeography: Atlantic, Mediterranean and Indo-Pacific regions. In Tsuchi, R., Ikebe, N., and IGCP Project 114 (Eds.), Pacific Neogene Datum Planes: Contributions to Biostratigraphy and Chronology: Tokyo (Univ. Tokyo Press), 111-161.

Berggren, W.A., Kent, D.V., and Van Couvering, J.A., 1985. The Neogene, Part 2. Neogene geochronology and chronostratigraphy. In Snelling, N.J. (Ed.), The Chronology of the Geological Record. Mem.-Geol. Soc. London, 10:211-260. doi:10.1144/GSL.MEM.1985.010.01.18

Cita, M.B., 1973. Pliocene biostratigraphy and chronostratigraphy. In Ryan, W.B.F., Hsü, K.J., et al. Init. Repts. DSDP, 13: Washington, DC (U.S. Govt. Printing Office), 1343-1379. doi:10.2973/dsdp.proc.13.147-1.1973

Expedition 306 Scientists, 2005. North Atlantic climate 2. IODP Prel. Rept., 306. doi:10.2204/iodp.pr.306.2005

Hilgen, F.J., 1991a. Astronomical calibration of Gauss to Matuyama sapropels in the Mediterranean and implication for the geomagnetic polarity time scale. Earth Planet. Sci. Lett., 104(2-4):226-244. doi:10.1016/ 0012-821X(91)90206-W

Hilgen, F.J., 1991b. Extension of the astronomically calibrated (polarity) time scale to the Miocene/Pliocene boundary. Earth Planet. Sci. Lett., 107(2):349-368. doi:10.1016/0012-821X(91)90082-S

Iaccarino, S., 1985. Mediterranean Miocene and Pliocene planktic foraminifera. In Bolli, H.M., Saunders, J.B., and 
Perch-Nielsen, K. (Eds.), Plankton Stratigraphy: Cambridge (Cambridge Univ. Press), 283-314.

Kennett, J.P., and Srinivasan, M.S., 1983. Neogene Planktonic Foraminifera: A Phylogenetic Atlas: Stroudsburg, PA (Hutchinson Ross).

Lisiecki, L.E., and Raymo, M.E., 2005. A Pliocene-Pleistocene stack of 57 globally distributed benthic $\delta^{18} \mathrm{O}$ records. Paleoceanography, 20(1):PA1003. doi:10.1029/ 2004PA001071

Lourens, L.J., Antonarakou, A., Hilgen, F.J., Van Hoof, A.A.M., Vergnaud-Grazzini, C., and Zachariasse, W.J., 1996a. Evaluation of the Plio-Pleistocene astronomical timescale. Paleoceanography, 11(4):391-414. doi:10.1029/96PA01125

Lourens, L.J., Hilgen, F.J., and Raffi, I., 1998. Base of large Gephyrocapsa and astronomical calibration of early Pleistocene sapropels in Site 967 and Hole 969D: solving the chronology of the Vrica section (Calabria, Italy). In Robertson, A.H.F., Emeis, K.-C., Richter, C., and Camerlenghi, A. (Eds.), Proc. ODP, Sci. Results, 160: College Station, TX (Ocean Drilling Program), 191-197. doi:10.2973/odp.proc.sr.160.017.1998

Lourens, L.J., Hilgen, F.J., Raffi, I., and Vergnaud-Grazzini, C., 1996b. Early Pleistocene chronology of the Vrica section (Calabria, Italy). Paleoceanography, 11(6):797-812. doi:10.1029/96PA02691

Raymo, M.E., Ruddiman, W.F., Backman, J., Clement, B.M., and Martinson, D.G., 1989. Late Pliocene variation in Northern Hemisphere ice sheets and North Atlantic deep water circulation. Paleoceanography, 4(4):413-446. doi:10.1029/PA004i004p00413
Stein, R., Kanamatsu, T., Alvarez-Zarikian, C., Higgins, S.M., Channell, J.E.T., Aboud, E., Ohno, M., Acton, G.D., Akimoto, K., Bailey, I., Bjørklund, K.R., Evans, H., Nielsen, S.H.H., Fang, N., Ferretti, P., Gruetzner, J., Guyodo, Y.J.B., Hagino, K., Harris, R., Hatakeda, K., Hefter, J., Judge, S.A., Kulhanek, D.K., Nanayama, F., Rashid, H., Sierro Sanchez, F.J., Voelker, A., and Zhai, Q., 2006. North Atlantic paleoceanography: the last five million years. Eos, Trans. Am. Geophys. Union, 87(13):129-133. doi:10.1029/2006E0130002

Weaver, P.P.E., 1987. Late Miocene to recent planktonic foraminifers from the North Atlantic: Deep Sea Drilling Project Leg 94. In Ruddiman, W.F., Kidd, R.B., Thomas, E., et al., Init. Repts. DSDP, 94: Washington (U.S. Govt. Printing Office), 703-727. doi:10.2973/ dsdp.proc.94.114.1987

Weaver, P.P.E., and Clement, B.M., 1986. Synchroneity of Pliocene planktonic foraminiferal datums in the North Atlantic. Mar. Micropaleontol., 10(4):295-307. doi:10.1016/0377-8398(86)90033-2

Weaver, P.P.E., and Clement, B.M., 1987. Magnetobiostratigraphy of planktonic foraminiferal datums: Deep Sea Drilling Project Leg 94, North Atlantic. In Ruddiman, W.F., Kidd, R.B., Thomas, E., et al., Init. Repts. DSDP, 94: Washington (U.S. Govt. Printing Office), 815829. doi:10.2973/dsdp.proc.94.120.1987

Initial receipt: 9 May 2008

Acceptance: 2 October 2008

Publication: 26 January 2009

MS 303306-205 
Figure F1. Globorotalia margaritae, Globorotalia puncticulata, and Globorotalia inflata relative abundance vs. depth, Site U1313. Arrows = event locations. FAO = first abundant occurrence, $\mathrm{LO}=$ last occurrence, $\mathrm{FO}=$ first occurrence.

\section{Depth $(\mathrm{mcd})$}
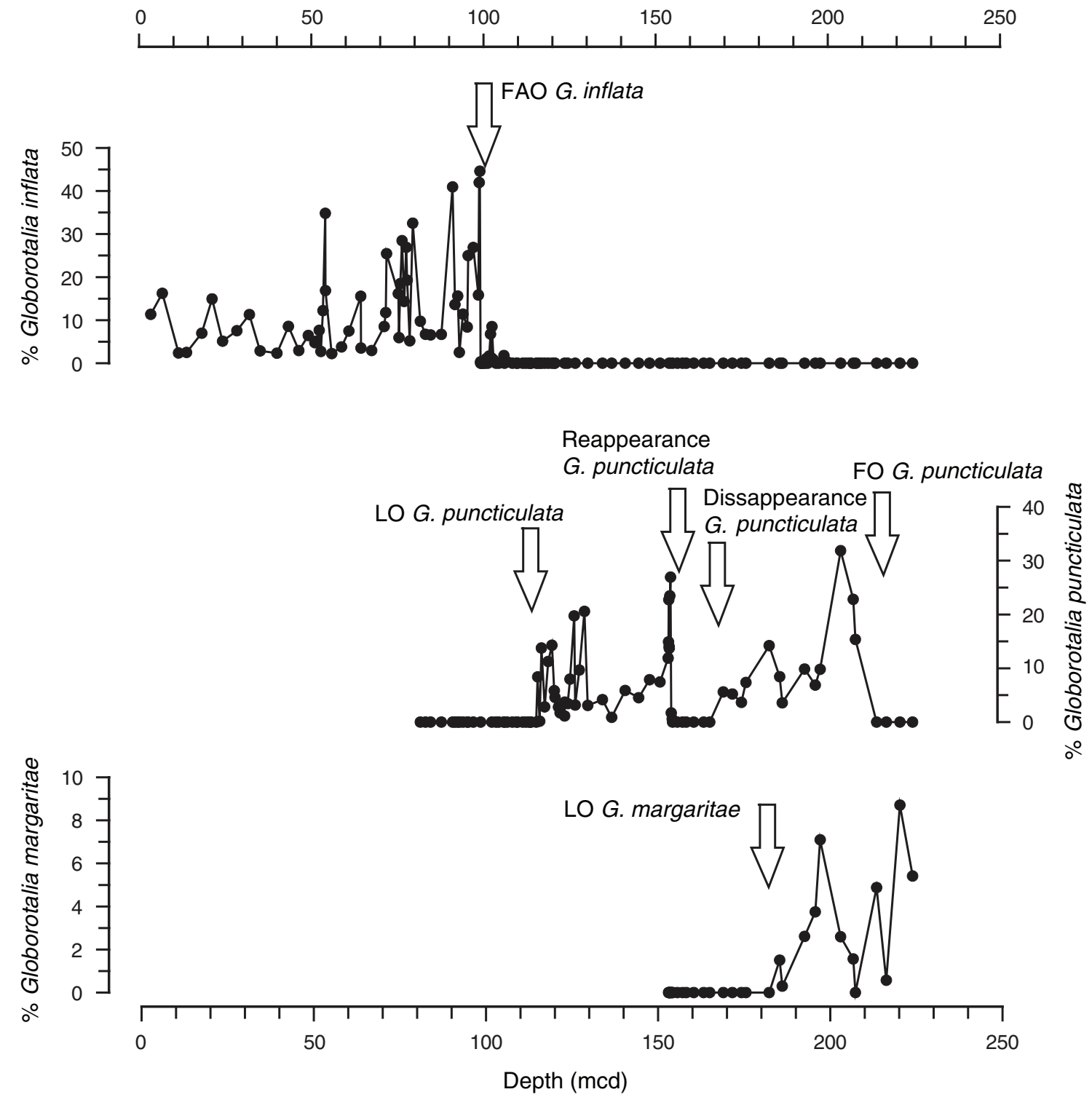
Figure F2. Globorotalia truncatulinoides, Neogloboquadrina pachyderma sinistral, and ratio between sinistral (sin) and dextral (dex) Neogloboquadrinids vs. depth, Site U1313. Arrows = event locations. FO = first occurrence, $\mathrm{FAO}=$ first abundant occurrence.
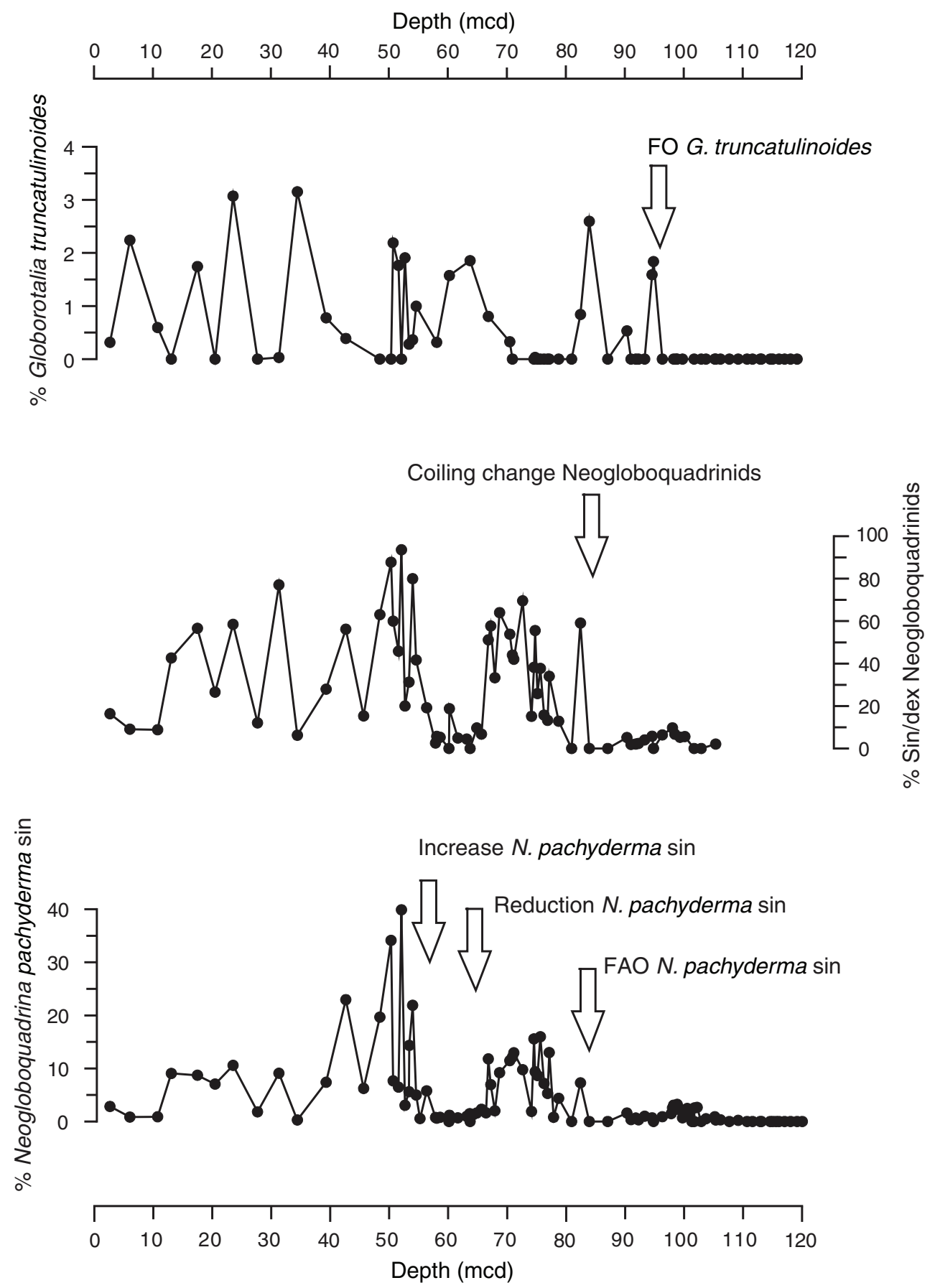
Figure F3. Correlation of the lightness $\left(\mathrm{L}^{*}\right)$ composite record measured in the upper $170 \mathrm{~m}$ of Site U1313 (Expedition 306 Scientists, 2005) with the global benthic oxygen isotope stack of Lisiecki and Raymo (2005) as proposed by Stein et al. (2006). Arrows = position of planktonic foraminifer bioevents, sin = sinistral. Magnetostratigraphy of Site U1313 from Expedition 306 Scientists (2005). FAO = first abundant occurrence, $\mathrm{LO}=$ last occurrence, $\sin =$ sinistral. $\mathrm{B} / \mathrm{M}=$ Brunhes/Matuyama, Jar. = Jaramillo, $\mathrm{C} / \mathrm{M}=$ Cobb Mountain/Matuyama, Old. $=$ Olduvai, $\mathrm{M} / \mathrm{G}=$ Matuyama/Gauss.
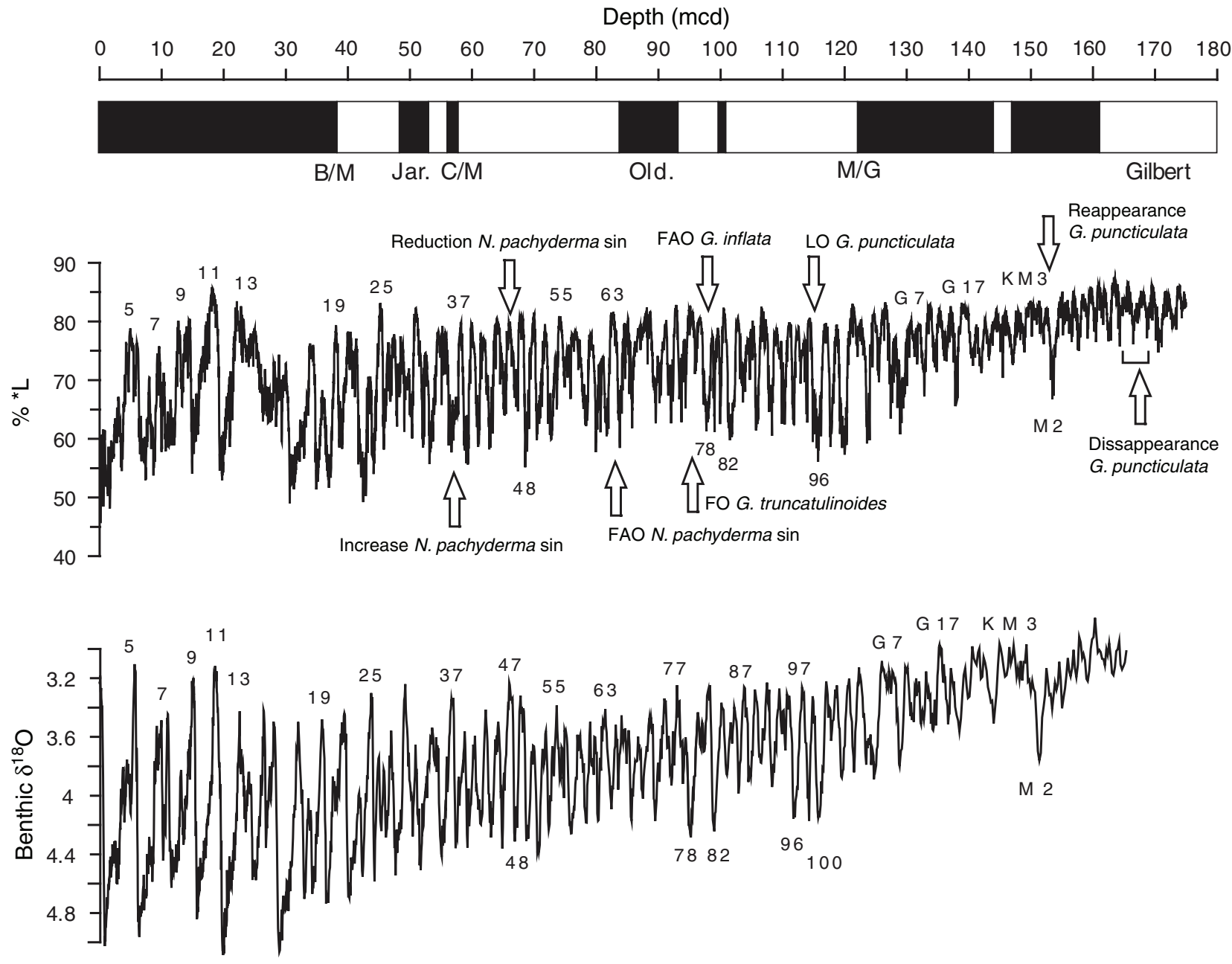

\begin{tabular}{|c|c|c|c|c|c|c|c|c|c|c|c|c|c|c|c|c|c|c|}
\hline Г & 1 & 1 & 1 & 1 & $T$ & $T$ & $T$ & $T$ & $T$ & $T$ & $T$ & $T$ & $T$ & 1 & $T$ & 1 & 1 & $\neg$ \\
\hline 0 & 0.2 & 0.4 & 0.6 & 0.8 & 1 & 1.2 & 1.4 & 1.6 & 1.8 & 2 & 2.2 & 2.4 & 2.6 & 2.8 & 3 & 3.2 & 3.4 & 3.6 \\
\hline
\end{tabular}


Table T1. Planktonic foraminifer quantitative data. (Continued on next two pages.)

\begin{tabular}{|c|c|c|c|c|c|c|c|c|c|}
\hline $\begin{array}{l}\text { Core, section, } \\
\text { interval }(\mathrm{cm})\end{array}$ & $\begin{array}{l}\text { Depth } \\
\text { (mcd) }\end{array}$ & $\begin{array}{c}\text { Total } \\
\text { planktonic } \\
\text { foraminifers }\end{array}$ & 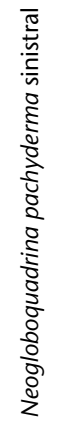 & 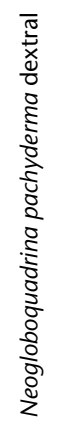 & 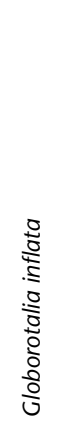 & 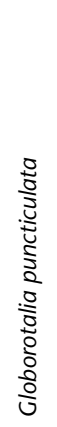 & 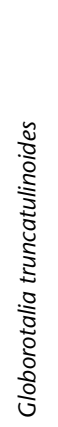 & 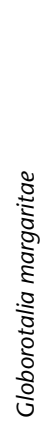 & 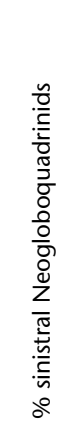 \\
\hline \multicolumn{10}{|l|}{$306-$} \\
\hline U1313C-1H-CC & 2.65 & 317 & 9 & 46 & 36 & 0 & 1 & & 16.36 \\
\hline U1313B-1H-CC & 6.02 & 357 & 3 & 30 & 58 & 0 & 8 & & 9.09 \\
\hline U1313D-2H-CC & 10.73 & 336 & 3 & 31 & 8 & 0 & 2 & & 8.82 \\
\hline U1313C-2H-CC & 13.05 & 320 & 29 & 39 & 8 & 0 & 0 & & 42.65 \\
\hline U1313B-2H-CC & 17.48 & 344 & 30 & 23 & 24 & 0 & 6 & & 56.60 \\
\hline U1313D-2H-CC & 20.47 & 241 & 17 & 47 & 36 & 0 & 0 & & 26.56 \\
\hline U1313C-3H-CC & 23.52 & 293 & 31 & 22 & 15 & 0 & 9 & & 58.49 \\
\hline U1313B-3H-CC & 27.67 & 384 & 7 & 51 & 29 & 0 & 0 & & 12.07 \\
\hline U1313D-3H-CC & 31.30 & 407 & 37 & 11 & 46 & 0 & 0 & & 77.08 \\
\hline U1313C-4H-CC & 34.42 & 349 & 1 & 15 & 10 & 0 & 11 & & 6.25 \\
\hline U1313B-4H-CC & 39.30 & 257 & 19 & 49 & 6 & 0 & 2 & & 27.94 \\
\hline U1313D-4H-CC & 42.64 & 257 & 59 & 46 & 22 & 0 & 1 & & 56.19 \\
\hline U1313C-5H-CC & 45.66 & 305 & 19 & 105 & 9 & 0 & & & 15.32 \\
\hline U1313A-5H-CC & 48.41 & 295 & 58 & 34 & 19 & 0 & 0 & & 63.04 \\
\hline U1313B-5H-CC & 50.31 & 293 & 100 & 14 & 14 & 0 & 0 & & 87.72 \\
\hline U1313B-6H-1, 72-73 & 50.66 & 274 & 21 & 14 & 14 & & 6 & & 60.00 \\
\hline U1313B-6H-1, 132-133 & 51.57 & 340 & 22 & 26 & 26 & & 6 & & 45.83 \\
\hline U1313B-6H-2, 32-33 & 52.07 & 183 & 73 & 5 & 5 & & 0 & & 93.59 \\
\hline U1313B-6H-2, 92-93 & 52.67 & 262 & 8 & 32 & 32 & & 5 & & 20.00 \\
\hline U1313B-6H-3, 10-11 & 53.35 & 356 & 20 & 44 & 124 & & 1 & & 31.25 \\
\hline U1313D-5H-CC & 53.40 & 237 & 34 & & 40 & 0 & & & \\
\hline U1313B-6H-3, 72-73 & 53.97 & 274 & 60 & 15 & & & 1 & & 80.00 \\
\hline U1313B-6H-3, 132-133 & 54.57 & 301 & 15 & 21 & & & 3 & & 41.67 \\
\hline U1313C-6H-CC & 55.22 & 358 & 2 & 5 & 8 & 0 & & & \\
\hline U1313B-6H-5, 10-11 & 56.35 & 415 & 24 & 101 & & & & & 19.20 \\
\hline U1313B-6H-6, 10-11 & 57.85 & 526 & 4 & 151 & & & & & 2.58 \\
\hline U1313A-6H-CC & 58.06 & 316 & 2 & 33 & 12 & 0 & 1 & & 5.71 \\
\hline U1313C-7H-2, 10-11 & 58.63 & 503 & 4 & 72 & & & & & 5.26 \\
\hline U1313C-7H-3, 10-11 & 60.13 & 413 & 0 & 23 & & & & & 0.00 \\
\hline U1313B-6H-CC & 60.20 & 254 & 3 & 13 & 19 & 0 & 4 & & 18.75 \\
\hline U1313C-7H-4, 10-11 & 61.63 & 436 & 3 & 58 & & & & & 4.92 \\
\hline U1313C-7H-5, 11-12 & 63.14 & 410 & 4 & 86 & & & & & 4.44 \\
\hline U1313C-7H-5, 62-63 & 63.65 & 270 & 4 & & 42 & & & & \\
\hline U1313D-6H-CC & 63.71 & 539 & 0 & 38 & 19 & 0 & 10 & & \\
\hline U1313C-7H-5, 122-123 & 64.25 & 228 & 3 & & & & & & \\
\hline U1313C-7H-6, 32-33 & 64.85 & 374 & 6 & 56 & & & & & 9.68 \\
\hline U1313B-7H-3, 135-136 & 65.64 & 391 & 9 & 124 & & & & & 6.77 \\
\hline U1313B-7H-4, 62-63 & 66.41 & 306 & 5 & & & & & & \\
\hline U1313C-7H-CC & 66.81 & 373 & 44 & 42 & 11 & 0 & 3 & & 51.16 \\
\hline U1313B-7H-4, 142-143 & 67.21 & 216 & 15 & 11 & & & & & 57.69 \\
\hline U1313B-7H-5, 62-63 & 67.91 & 247 & 5 & 10 & & & & & 33.33 \\
\hline U1313B-7H-5, 142-143 & 68.71 & 174 & 16 & 9 & & & & & 64.00 \\
\hline U1313A-7H-CC & 70.44 & 305 & 35 & 30 & 26 & 0 & 1 & & 53.85 \\
\hline U1313B-7H-CC & 70.89 & 272 & 33 & 42 & 32 & 0 & 0 & & 44.00 \\
\hline U1313C-8H-3, 10-11 & 71.13 & 224 & 29 & 40 & 57 & & & & 42.03 \\
\hline U1313C-8H-4, 10-11 & 72.63 & 328 & 32 & 14 & & & & & 69.57 \\
\hline U1313C-8H-5, 10-11 & 74.13 & 264 & 5 & 28 & & & & & 15.15 \\
\hline U1313B-8H-2, 51-52 & 74.54 & 167 & 26 & 42 & 27 & 0 & 0 & & 38.24 \\
\hline U1313D-7H-CC & 74.74 & 320 & 30 & 24 & 19 & 0 & 0 & & 55.56 \\
\hline U1313B-8H-2, 111-112 & 75.14 & 254 & 22 & 63 & 47 & 0 & 0 & & 25.88 \\
\hline U1313B-8H-3, 10-11 & 75.63 & 144 & 23 & 38 & 41 & 0 & 0 & & 37.70 \\
\hline U1313B-8H-3, 72-73 & 76.25 & 237 & 17 & 91 & 34 & 0 & 0 & & 15.74 \\
\hline U1313B-8H-3, 132-133 & 76.85 & 208 & 11 & 72 & 56 & 0 & 0 & & 13.25 \\
\hline U1313B-8H-4, 10-11 & 77.13 & 254 & 33 & 64 & 49 & 0 & 0 & & 34.02 \\
\hline U1313C-8H-CC & 77.87 & 250 & 2 & 9 & 13 & 0 & & & \\
\hline U1313C-9H-2, 10-11 & 78.73 & 206 & 9 & 61 & 67 & 0 & 0 & & 12.86 \\
\hline
\end{tabular}


Table T1 (continued). (Continued on next page.)

\begin{tabular}{|c|c|c|c|c|c|c|c|c|c|}
\hline $\begin{array}{l}\text { Core, section, } \\
\text { interval }(\mathrm{cm})\end{array}$ & $\begin{array}{l}\text { Depth } \\
\text { (mcd) }\end{array}$ & $\begin{array}{c}\text { Total } \\
\text { planktonic } \\
\text { foraminifers }\end{array}$ & 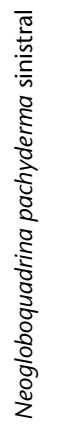 & 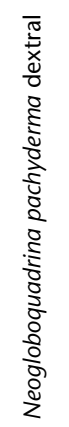 & 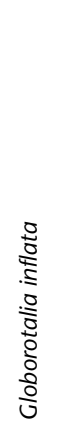 & 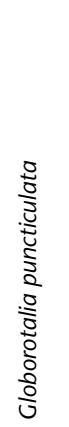 & 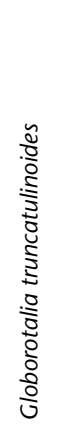 & 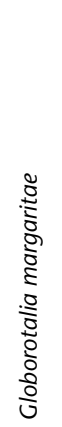 & 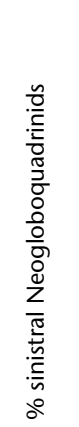 \\
\hline U1313A-8H-CC & 80.93 & 277 & 0 & 16 & 27 & 0 & 0 & & 0.00 \\
\hline U1313B-8H-CC & 82.43 & 357 & 26 & 18 & 24 & 0 & 3 & & 59.09 \\
\hline U1313D-8H-CC & 83.92 & 655 & 0 & 158 & 43 & 0 & 17 & & 0.00 \\
\hline U1313C-9H-CC & 87.05 & 284 & 0 & 8 & 19 & 0 & 0 & 0 & 0.00 \\
\hline U1313C-10H-2, 10-11 & 90.31 & 188 & 3 & 55 & 77 & 0 & 1 & & 5.17 \\
\hline U1313A-9H-CC & 91.00 & 286 & 1 & 51 & 39 & 0 & 0 & & 1.92 \\
\hline U1313C-10H-3, 10-11 & 91.81 & 301 & 2 & 93 & 47 & 0 & 0 & & 2.11 \\
\hline U1313B-9H-CC & 92.27 & 317 & 1 & 41 & 8 & 0 & 0 & & 2.38 \\
\hline U1313C-10H-4, 10-11 & 93.31 & 298 & 3 & 71 & 34 & 0 & 0 & & 4.05 \\
\hline U1313D-9H-CC & 94.57 & 440 & 3 & 49 & 37 & 0 & 7 & & 5.77 \\
\hline U1313C-10H-5, 10-11 & 94.81 & 272 & 0 & 24 & 68 & 0 & 5 & & 0.00 \\
\hline U1313B-10H-3, 10-11 & 96.31 & 331 & 3 & 44 & 89 & 0 & 0 & & 6.38 \\
\hline U1313B-10H-4, 10-11 & 97.81 & 202 & 3 & & 32 & & & & \\
\hline U1313B-10H-4, 32-33 & 98.03 & 274 & 7 & 65 & 115 & & & & 9.72 \\
\hline U1313B-10H-4, 52-53 & 98.23 & 260 & 8 & & 116 & & 0 & & \\
\hline U1313B-10H-4, 72-73 & 98.43 & 311 & 7 & 97 & 1 & & & & 6.73 \\
\hline U1313C-10H-CC & 98.45 & 300 & & & 0 & 0 & & & \\
\hline U1313B-10H-4, 92-93 & 98.63 & 260 & 8 & & 0 & & 0 & & \\
\hline U1313B-10H-4, 112-113 & 98.83 & 372 & 12 & & 0 & & 0 & & \\
\hline U1313B-10H-5, 10-11 & 99.31 & 450 & 10 & 179 & 0 & & & & 5.29 \\
\hline U1313B-10H-5, 52-53 & 99.73 & 287 & 2 & & 0 & & 0 & & \\
\hline U1313B-10H-5, 92-93 & 100.13 & 278 & 6 & 101 & 3 & & & & 5.61 \\
\hline U1313B-10H-5, 132-133 & 100.53 & 244 & 6 & & 0 & & & & \\
\hline U1313C-11H-2, 32-33 & 100.93 & 180 & 2 & & 3 & & & & \\
\hline U1313C-11H-2, 72-73 & 101.33 & 251 & 0 & & 17 & & & & \\
\hline U1313A-10H-CC & 101.70 & 262 & 0 & 60 & 3 & 0 & 0 & & 0.00 \\
\hline U1313C-11H-2, 112-113 & 101.73 & 235 & 6 & & 20 & & & & \\
\hline U1313C-11H-3, 10-11 & 102.21 & 263 & 7 & & 2 & & & & \\
\hline U1313B-10H-CC & 102.90 & 448 & 0 & 50 & 0 & 0 & 0 & & 0.00 \\
\hline U1313C-11H-4, 10-11 & 103.71 & 193 & 1 & & 0 & 0 & 0 & & \\
\hline U1313C-11H-5, 10-11 & 105.21 & 224 & 2 & & 4 & 0 & 0 & & \\
\hline U1313D-10H-CC & 105.36 & 351 & 1 & 47 & 0 & 0 & 0 & & 2.08 \\
\hline U1313B-11H-3, 10-11 & 106.17 & 319 & 1 & & 1 & 0 & 0 & & \\
\hline U1313B-11H-4, 10-11 & 107.67 & 272 & 0 & & 0 & 0 & 0 & & \\
\hline U1313C-11H-CC & 108.87 & 300 & & & 0 & 0 & & & \\
\hline U1313B-11H-5, 10-11 & 109.17 & 463 & 1 & & 0 & 0 & 0 & & \\
\hline U1313B-11H-6, 10-11 & 110.67 & 218 & 0 & & 0 & 0 & 0 & & \\
\hline U1313C-12H-2, 10-11 & 111.60 & 253 & 0 & & 0 & 0 & 0 & & \\
\hline U1313A-11H-CC & 112.52 & 300 & & & 0 & 0 & & & \\
\hline U1313B-11H-CC & 112.92 & 350 & 0 & & 0 & 0 & 0 & & \\
\hline U1313C-12H-3, 10-11 & 113.10 & 253 & 0 & & 0 & 0 & 0 & & \\
\hline U1313C-12H-4, 10-11 & 114.60 & 161 & 0 & & 0 & 0 & 0 & & \\
\hline U1313C-12H-4, 52-53 & 115.02 & 238 & 0 & & 0 & 20 & 0 & & \\
\hline U1313D-11H-CC & 115.60 & 1200 & 0 & & 0 & 2 & & & \\
\hline U1313C-12H-5, 10-11 & 116.10 & 327 & 0 & & 0 & 45 & 0 & & \\
\hline U1313B-12H-3, 10-11 & 117.04 & 177 & 0 & & 0 & 5 & 0 & & \\
\hline U1313B-12H-3, 112-113 & 118.06 & 222 & 0 & & 0 & 25 & 0 & & \\
\hline U1313B-12H-4, 72-73 & 119.16 & 357 & 0 & & 0 & 51 & 0 & & \\
\hline U1313C-12H-CC & 119.83 & 428 & & & 0 & 25 & & & \\
\hline U1313B-12H-5, 10-11 & 120.04 & 283 & 0 & & 0 & 13 & & & \\
\hline U1313B-12H-5, 112-113 & 121.06 & 214 & & & & 6 & & & \\
\hline U1313B-12H-6, 10-11 & 121.54 & 233 & & & & 4 & & & \\
\hline U1313A-12H-CC & 122.84 & 350 & & & 0 & 4 & & & \\
\hline U1313C-13H-3, 10-11 & 122.90 & 215 & & & & 8 & & & \\
\hline U1313B-12H-CC & 123.74 & 292 & & & 0 & 10 & & & \\
\hline U1313C-13H-4, 10-11 & 124.40 & 313 & & & & 25 & & & \\
\hline U1313B-13H-2, 10-11 & 125.61 & 233 & & & & 46 & & & \\
\hline U1313D-12H-CC & 125.91 & 378 & & & 0 & 12 & & & \\
\hline
\end{tabular}


Table T1 (continued).

\begin{tabular}{|c|c|c|c|c|c|c|c|c|c|}
\hline $\begin{array}{l}\text { Core, section, } \\
\text { interval }(\mathrm{cm})\end{array}$ & $\begin{array}{l}\text { Depth } \\
\text { (mcd) }\end{array}$ & $\begin{array}{c}\text { Total } \\
\text { planktonic } \\
\text { foraminifers }\end{array}$ & 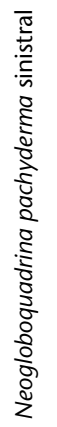 & 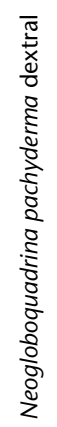 & 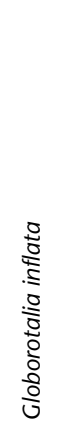 & 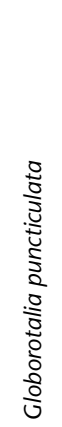 & 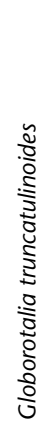 & 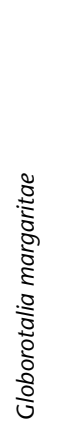 & 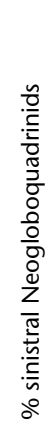 \\
\hline U1313B-13H-3, 10-11 & 127.11 & 186 & & & & 18 & & & \\
\hline U1313B-13H-4, 10-11 & 128.61 & 243 & & & & 50 & & & \\
\hline U1313C-13H-CC & 129.56 & 323 & & & 0 & 10 & & & \\
\hline U1313B-13H-CC & 133.83 & 288 & & & 0 & 12 & & & \\
\hline U1313D-13H-CC & 136.51 & 680 & 0 & & 0 & 6 & & & \\
\hline U1313C-14H-CC & 140.43 & 340 & & & 0 & 20 & & & \\
\hline U1313B-14H-CC & 144.35 & 375 & & & 0 & 17 & & & \\
\hline U1313D-14H-CC & 147.50 & 406 & & & 0 & 32 & & & \\
\hline U1313C-15H-CC & 150.54 & 362 & & & 0 & 27 & & 0 & \\
\hline U1313B-15H-6, 112-113 & 152.90 & 227 & & & & 27 & & & \\
\hline U1313C-16H-2, 52-53 & 153.00 & 322 & & & & 48 & & & \\
\hline U1313B-15H-6, 132-133 & 153.10 & 365 & & & & 83 & & & \\
\hline U1313C-16H-2, 72-73 & 153.20 & 228 & & & & 32 & & & \\
\hline U1313A-15H-CC & 153.21 & 350 & & & 0 & 48 & & & \\
\hline U1313C-16H-2, 92-93 & 153.40 & 375 & & & & 88 & & & \\
\hline U1313C-16H-2, 112-113 & 153.60 & 401 & & & & 108 & & & \\
\hline U1313C-16H-2, 132-133 & 153.80 & 352 & & & & 6 & & & \\
\hline U1313C-16H-3, 10-11 & 154.08 & 359 & & & & 2 & & & \\
\hline U1313B-15H-CC & 154.17 & 365 & & & 0 & 0 & & & \\
\hline U1313C-16H-4, 10-11 & 155.58 & 209 & 0 & & 0 & 0 & 0 & & \\
\hline U1313C-16H-5, 10-11 & 157.08 & 217 & 0 & & 0 & 0 & 0 & & \\
\hline U1313D-15H-CC & 158.17 & 409 & & & 0 & 0 & & & \\
\hline U1313C-16H-CC & 160.34 & 380 & & & 0 & 0 & & 0 & \\
\hline U1313A-16H-CC & 163.21 & 320 & & & 0 & 0 & & & \\
\hline U1313B-16H-CC & 164.97 & 363 & & & 0 & 0 & & & \\
\hline U1313D-16H-CC & 168.92 & 410 & & & 0 & 23 & & & \\
\hline U1313C-17H-CC & 171.55 & 326 & & & 0 & 17 & & 0 & \\
\hline U1313A-17H-CC & 174.19 & 300 & & & 0 & 11 & & & \\
\hline U1313B-17H-CC & 175.49 & 475 & & & 0 & 35 & & & \\
\hline U1313C-18H-CC & 182.25 & 366 & & & 0 & 52 & & 0 & \\
\hline U1313A-18H-CC & 185.29 & 332 & & & 0 & 28 & & 5 & \\
\hline U1313B-18H-CC & 186.05 & 335 & & & 0 & 12 & & 1 & \\
\hline U1313C-19H-CC & 192.52 & 345 & & & 0 & 34 & & 9 & \\
\hline U1313A-19H-CC & 195.63 & 320 & & & 0 & 22 & & 12 & \\
\hline U1313B-19H-CC & 197.05 & 479 & & & 0 & 47 & & 34 & \\
\hline U1313C-20H-CC & 203.00 & 270 & & & 0 & 86 & & 7 & \\
\hline U1313A-20H-CC & 206.65 & 320 & & & 0 & 73 & & 5 & \\
\hline U1313B-20H-CC & 207.29 & 358 & & & 0 & 55 & & 0 & \\
\hline U1313C-21H-CC & 213.44 & 328 & & & 0 & 0 & & 16 & \\
\hline U1313A-21H-CC & 216.26 & 350 & & & 0 & 0 & & 2 & \\
\hline U1313B-21H-CC & 220.21 & 620 & & & 0 & 0 & & 54 & \\
\hline U1313C-22H-CC & 223.89 & 351 & & & 0 & 0 & & 19 & \\
\hline
\end{tabular}

